\title{
MATAS CILIARES E DEGRADAÇÃO DA PAISAGEM NO MÉDIO IGUAÇU EM RELAÇÃO À EDUCAÇÃO AMBIENTAL ${ }^{1}$.
}

\author{
Helena Edilamar Ribeiro Buch ${ }^{2}$
}

\begin{abstract}
Este texto constitui em uma análise no Médio Iguaçu, as alterações ambientais decorrentes da ação antrópica, considerando os reflexos na bacia hidrográfica e na destruição da mata ciliar durante e depois da navegação a vapor no Médio rio Iguaçu com a exploração da madeira, seguida pelas construções das ferrovias e atualmente pela exploração de areia. Aponta que somente através da educação ambiental na forma de compromisso e mudança de atitude, se vislumbra um futuro melhor. Para isso, fez-se necessário conhecer os mais importantes indicadores das condições ambientais da área ao longo do seu processo de ocupação, condições naturais em diferentes fases temporais: Ocupação dos pioneiros; Durante o processo da urbanização;com a expansão,das cidades e o aumento da área agricultável. Depois das principais intervenções humanas, verificadas na expedição ao rio em 2001. Desta forma o uso da terra expressa as relações econômicas da região e destaca as alterações ambientais fomentando a construção de valores ambientais na população em idade escolar, veículos do saber futuro. Através da Agenda 21" Protegendo a vida do rio",que será,construída pelos próprios alunos das escolas, que recebem mais influência Médio Iguaçu sendo eles próprios os multiplicadores das idéias de proteção ao rio.
\end{abstract}

PALAVRAS-CHAVE: mata ciliar; paisagem; educação; ambiental.

\footnotetext{
${ }^{1}$ Orientador: Prof. Dr. Naldy Emerson Canali

2 Mestranda em Geografia (UFPR) - e-mail: edilamarbucha@hotmail.com
} 